\title{
Second Language Grammatical Proficiency and Third Language Acquisition
}

\author{
Laleh Moghtadi ${ }^{1}$, Mansour Koosha ${ }^{1} \&$ Ahmad Reza Lotfi ${ }^{1}$ \\ ${ }^{1}$ Department of Foreign Languages, Isfahan (Khorasgan) Branch, Islamic Azad University, Isfahan, Iran \\ Correspondence: Laleh Moghtadi, Department of Foreign Languages, Isfahan (Khorasgan) Branch, Islamic Azad \\ University, Isfahan, Iran. E-mail: 1_moghtadi@yahoo.com
}

Received: August 12, 2014

doi:10.5539/ies.v7n11p19
Accepted: September 22, 2014 Online Published: October 28, 2014

URL: http://dx.doi.org/10.5539/ies.v7n11p19

\begin{abstract}
The main concern of the present study was to investigate the probable correlation between the bilinguals' second language grammatical proficiency level and their third language grammatical proficiency level. The current study was implemented on selecting a total of 100 Iranian female high school students studying at second grade from two educational districts of Tabriz (an Azeri-speaking city in Iran). The participants were homogeneous in terms of their English proficiency level (achieved through the Oxford Solutions Placement Test), sex, and age. They attended public high schools; they were taught the same material and they had the same number of hours of instruction. Two grammatical proficiency tests (Persian and English), a background questionnaire were administered to the participants. Statistical analyses including descriptive statistics and a Spearman's Rho Correlation revealed a significant correlation between the bilinguals' second language grammatical proficiency level and their third language grammatical proficiency level. Finally, the implications of the results as they relate to educational programs were discussed.
\end{abstract}

Keywords: bilingualism, grammatical knowledge, third language acquisition

\section{Introduction}

According to Cenoz (2008), going beyond second language acquisition (SLA) to the third language acquisition (TLA) is very common for many people all over the world. Generally speaking, TLA refers to "the acquisition of a non-native language by learners who have previously acquired or are acquiring two other languages. The acquisition of the first two languages can be simultaneous (as in early bilingualism) or consecutive" (Cenoz, 2003, p.71).

In the field of language acquisition, TLA is a relatively new area of research and it is scarce in comparison to that already carried out into SLA and first language acquisition (FLA). According to Cenoz and Jessner (2000) research into specific characteristics of TLA is still in its infancy. "One of the first true L3 acquisition studies is the one by Stedje and Biedermann (1975) and Stedje (1977), in which the acquisition of German as an L2 is compared to the acquisition of German as an L3 “(Falk, 2010, p. 12).

However, the young and under-explored field of TLA research has experienced important developments in recent years (e.g. Ringbom, 1987; Cenoz \& Genesee, 1998; Cenoz \& Jessner, 2000; Edwards, 1994; Cenoz, Hufeisen, \& Jessner, 2001, 2003; Cenoz, 2000, 2003, 2009). It has focused on different areas such as the influence of bilingualism on TLA (Thomas, 1988; Swain, Lapkin, Rowen, \& Hart, 1990; Sanz, 2000), cross-linguistic influence and interaction (Williams \& Hammarberg, 1998; Hufeisen, 2000), to name a few.

The scholars who actively work on TLA (Cenoz \& Jessner, 2000; Cenoz, 2000) generally support this view that TLA is qualitatively different from SLA and FLA and it presents more diversity and complexity than SLA resulting in situations which are unique in language acquisition.

Admittedly, TLA is a more complex process than SLA due to the involvement of the confounding factors such as typology, proficiency, recency, etc (Falk \& Bardel, 2010). A number of studies over the last three decades have proved that good proficiency in previously learned languages leads to general proficiency in an L3.

During the past several decades, there has been an increased interest in this relatively young field. Cenoz (2001) believes that the learners who are learning a foreign language are not always monolinguals, especially; those who are members of linguistic minorities in their countries. Iran sets a real example of those countries in which 
many English learners are members of linguistic minorities like Arab, Turk, and Kurd. In Iran, a multicultural and multilingual society, TLA has still been subsumed under research on SLA except for a few studies such as Keshavarz and Astaneh (2004); Modirkhamene (2008); Farhadian et al. (2010); Kassaian and Esmae'li (2011); Saeidi and Mazoochi (2013) and Khany and Bazyar (2014) to name a few.

While the studies explored the issue of TLA in Iran have investigated a group of variables in relation to the third language (L3) development (e.g., autonomy and motivation, among others), still one possibly significant relation that has been overlooked is that between the bilinguals' level L2 grammatical knowledge and their L3 grammatical knowledge. According to Lasagabaster (2000) and Sanz (2000) proficiency plays a crucial role in TLA (as it may affect the L3 learner's successful acquisition of an L3). Therefore, an argument can be made that further research still needs to be conducted in order to better understand whether there is a relationship between L2 grammatical knowledge and TLA. In other words, the aim of this study is to compare students' grammatical proficiency in their L2 (Persian) to their L3 grammatical proficiency (English).It is hypothesized that higher grammatical proficiency in the L2 will increase the grammatical proficiency level in the L3.

\subsection{Proficiency Studies}

In an attempt, Lasagabaster (2000) compared the level of proficiency in Basque, Spanish and English attained by the students. The participants were of Basque-Spanish bilingual and Spanish monolingual children in the Basque Country. Based on Cummins' (1976) 'threshold' hypothesis and 'developmental interdependence' hypothesis, Lasagabaster (2000) assumed that high levels of competence in both languages, Basque and Spanish, would lead to high levels of achievement in L3. On the other hand, low levels of competence in Basque and Spanish would lead to low command of the L3 because of lowly developed common underlying proficiency. Competence in English was measured via a vocabulary and a grammar test. The results clearly indicated that "if a high degree of competence is achieved in L1 and L2, then the L3 can be seen as having a beneficial effect in that it may promote and assist the development of greater metalinguistic awareness" (Lasagabaster, 2000, p. 195).

In the same year, Sanz (2000) and Muñoz (2000) found similar results. Sanz (2000) compared the L3 English acquisition of Catalan-Spanish bilinguals with the L2 English acquisition of Spanish monolinguals. All the participants completed the vocabulary and structure sections of the CELT English proficiency test. Other factors such as general intelligence, exposure, attitudes, motivation and socioeconomic status were also controlled. Based on a hierarchical multiple regression analysis, Sanz (2000) concluded that high level of proficiency in an L2 facilitated the process of learning an L3.

Muñoz (2000), furthermore, conducted a study in Catalonia and compared three groups of subjects in different Grades. The main hypothesis of the study, which was high levels of proficiency in L1 and L2 would correlate positively with a high level of proficiency in L3, was confirmed through the use of the experimental instruments. The results indicated that learners with a high level of proficiency in two other languages also presented a high level of proficiency in English as the L3.

Outside the Basque Country and Catalonia, the results of the studies were the same as those conducted inside the Basque Country and Catalonia. As cited in Cenoz (2003), Brohy's (2001) study of the L3 French acquisition by Romansch-German bilinguals and German-speaking monolinguals in Switzerland, for example, reached the same conclusion as the other studies; i.e. bilinguals obtain higher levels of proficiency in a third language.

In sum, studies on the effect of language proficiency in an L3 conducted in different contexts tend to associate high proficiency in previously learned languages with advantages in TLA. However, not all research studies report positive effects. For example, Jaspaert and Lemmens (1990) compared the level of proficiency in Dutch of Italian-French bilinguals to that of French-speaking monolinguals and found no differences between them (as cited in Cenoz, 2003).

Therefore, according to scholars such as Lindqvist (2009) and Bardel and Lindqvist (2007), one of the important factors in TLA is the proficiency level in the L2 and L3: the high proficiency level of the L3, the less activation of a low-proficiency background language and the more activation of a high-proficiency L2 or the L1.

\subsection{Theoretical Framework}

According to Bachman's (1990) and Bachman and Palmer's (1996) multi-componential model of communicative language ability, language knowledge has two general components: (1) organizational knowledge and (2) pragmatic knowledge. Organizational knowledge, defined as how individuals control language structure to produce grammatically correct utterances or sentences and texts, is further divided into grammatical knowledge and textual knowledge. Grammatical knowledge is defined as knowledge of vocabulary, syntax, and phonology/graphology. Grammatical knowledge governs "the choice of words to express specific 
significations, their forms, their arrangement in utterances to express propositions, and their physical realizations, either as sounds or as written symbols" (Bachman, 1990, p. 87). In Bachman and Palmer's (1996) view, grammatical knowledge refers to several components of linguistic form relating strictly to sentence-based phonology, graphology, vocabulary and syntax.

Larsen-Freeman (1991) has also characterized grammatical knowledge along three dimensions: linguistic form, semantic meaning and pragmatic use. "Grammatical structures not only have (morphosyntactic) form, they are also used to express meaning (semantics) in context appropriate use (pragmatics) (Larsen-Freeman, 1991, p. 252)". According to her, these three dimensions may be viewed as independent or interconnected.

According to Purpura, (2004), grammatical knowledge has two highly related components: grammatical form and grammatical meaning. Grammatical form refers to "linguistic forms on the subsentential, sentential and suprasentential levels, as described in the syntactocentric approaches to language discussed previously" (Purpura, 2004, p. 61). Grammatical form includes phonological/graphological forms, lexical forms, morphosyntactic forms, cohesive forms, information management forms, and interactional forms.

Grammatical meaning refers to knowledge of the meaning associated with an utterance as the sum of its parts and how these parts are arranged in syntax (literal meaning), as well as how these parts are used to convey the speaker's intended meaning in context (intended meaning). (Purpura, 2004, p. 61)

Grammatical meaning includes phonological/graphological meanings, lexical meanings, morphosyntactic meanings, cohesive meanings, information management meanings, and interactional meanings.

In this study, the researcher adopted the notion of grammatical knowledge as knowledge of vocabulary and grammatical structure. This is because lexical and syntactic knowledge seems to be the clearest examples to represent grammatical proficiency as it included in many models of language proficiency, although there are differences in terminologies and categorizations of these types of knowledge.

\subsection{Research Questions}

To accumulate the relevant evidence, the following research question was formulated:

- Would L2 grammatical proficiency level (Persian) correlate with L3 grammatical proficiency level (English)?

\subsection{Research Hypotheses}

Based on the aforementioned question, the following null hypothesis was postulated and tested:

Ho1: L2 grammatical proficiency level (Persian) would not correlate with L3 grammatical proficiency level (English).

\section{Method}

\subsection{The Context for the Study}

Persian is an Indo-European language-a southwestern Iranian language from the Indo-Iranian branch, which is written with a modified Arabic alphabet. Persian is the first language of the majority of the population in Iran and the country's official language. It is the sole language of education and instruction.

Azeri is a member of the Oghuz branch of the Turkic languages. Azeri spoken in Iran is called South Azerbaijani. South Azeri, in Iran, uses the Perso-Arabic script although the spelling and orthography is not yet standardized.

All the bilingual children in Iran have Persian as the language of instruction, and they also studied English as a school subject. Although Persian is becoming the language of instruction in all areas of Iran, Azeri is the language at the community level in Tabriz (an Azeri-speaking city).The bilingual children learn and speak their L1 at home and don't receive any education in their native languages; like other Iranian students they start learning Persian literacy skills (reading and writing) at the age of seven and continue until their diploma. As a result, they become bilingual by speaking their mother tongue, Azeri, from birth and learning to read and write Persian at school.

\subsection{Design}

This study aimed at investigating the probable correlation between L2 grammatical proficiency level and L3 grammatical proficiency level in multilingual environment with Azeri as the L1, Persian as the L2 and English as the L3. The current study has attempted to uncover the relationship between L2 grammatical proficiency and TLA. Concerning the importance of L3 learning, therefore, this study employed an ex post-facto (causal-comparative) research design with a correlational analysis. An ex post-facto was considered to be 
suitable for this study since the researchers could not control or manipulate the variables under investigation because they had already occurred(Cohen, Manion, \& Morrison, 2007).The study applied research procedures for data collection (administering two proficiency tests, a background questionnaire to the participants) as well as research procedures for data analysis.

\subsection{Participants}

There were a total of 100 high school students studying at the second grade who participated in this study. There were all female participants aged between of 15 to 18 years $(M=15.68, S D=.62)$.

The participants were homogeneous in terms of the following factors: they attended public high schools; they were taught using the same materials; i.e. the textbooks and methodology for teaching English as a foreign language were the same (sanctioned by the Ministry of Education). They had the same number of hours of instruction, which was one session (one hour and thirty minutes) every week. They were also homogeneous in terms of their English proficiency level (achieved through the OSPT), sex, and age.

\subsection{Research Instruments}

\subsubsection{Background Information Questionnaire}

A background questionnaire was used to elicit information about participants' background and about the language repertoire of the participants. To have a better picture of the context in which participants were learning the languages they knew, they were asked to provide information about the educational level of their parents, their families' native tongues, and how many years of education they have received in their L1, L2 and L3 language(s) they use at school as well as the city from which they come. It should be noted that the questionnaire was written in Persian in order to avoid participants' English proficiency impinging upon their filling in the questionnaire, and since the bilingual group did not receive any education in their native language and could not read in their L1 Azeri.

\subsubsection{English Grammatical Proficiency Test}

In this study, an English proficiency test; i.e. Oxford Solutions Placement Test (OSPT) (Edwards, 2007) was utilized. The purpose of using this test was twofold. First, it was utilized to make sure of the homogeneity of the participants in terms of English proficiency level. Second, it was utilized to determine the bilinguals' proficiency in L3 English grammar.

As far as the English proficiency test was concerned, the researchers decided to use the OSPT rather than the Oxford Placement Test (OPT). The reason for this was that it was considered the OPT might not appropriately fit participants' language proficiency. The OPT may be too challenging for participants such as high school students and could lead them using guesswork to a certain extent: the validity and reliability of the test would then be diminished. Moreover, as grammar and vocabulary are heavily focused on in the Iranian EFL curriculum and since the aim of this study was to accumulate the relevant evidence concerning the bilinguals' grammatical proficiency level, the researchers decided to use the grammar and vocabulary sections of the OSPT instead.

The test consisted of 50 multiple choice items with an estimated time of 45 minutes for completion as had been determined in the OSPT. It was a paper-and-pencil test. Hence, the participants had to answer the questions in specified answer sheets. They had to read the stem with a blank and choose the right choice for the blank.

The reliability of the OSPT was calculated using the Cronbach Alpha coefficient which turned out to be .62. Besides, for the purpose of measuring the concurrent validity of this test, it was correlated with an achievement test developed by the Ministry of Education for the second-grades centers. The correlation coefficient calculated between the achievement test and the OSPT was found to be .91.

\subsubsection{Persian Grammatical Proficiency Test}

Persian Grammatical Proficiency Test (PGPT) was designed to determine the bilinguals'L2 grammatical proficiency. Based on Bachman's (1990) and Bachman and Palmer's (1996) view, the PGPT is comprised of Persian vocabulary and syntax. This is because lexical and syntactic knowledge seems to be the clearest examples to represent grammatical proficiency.

The first intention was to obtain a standardized test in order to ensure that the test was of good quality and fulfilled its purpose of being comparable to the OSPT. However, a standardized PGPT could not be obtained. Consequently, the researchers explored the university entrance exam (Konkor) questions, which include a wide variety of items. In the final version of the test, test items were drawn from the vocabulary and grammar test sections of five years' worth of Konkor questions which resulted in a test that could give the researcher an indication of the bilinguals' proficiency level in their L2 Persian grammatical knowledge. In order to make the 
test more effective, several test items were revised.

The test contained 50 multiple choice items aiming at assessing students' knowledge of key grammar and vocabulary. It was a paper-and-pencil test. Hence, the participants had to answer the questions in specified answer sheets. They had to read the stem with a blank and choose the right choice for the blank. The time allowed was 45 minutes.

The reliability of the PGPT was calculated using the Cronbach Alpha coefficient which turned out to be .65 . Besides, for the purpose of measuring the concurrent validity of this test, it was correlated with an achievement test developed by the Ministry of Education for the second-grades centers. The correlation coefficient calculated between the achievement test and the PGPT was found to be .93 .

\subsection{Data Collection Procedures}

The data collection phase comprised the administration of three instruments. At the first phase of the study, the researchers used oral description to explain the study to the students, giving brief instructions for all phases of the study. They reiterated that participants should not see the experiment as a 'test'. The questionnaire was then distributed.

Then, the grammatical proficiency tests were administered to the participants. That is, the OSPT was taken by participants on the second week and the PGPT on the third week. The tests were administered according to the test instructions including strict time limits (45 minutes).

\subsection{Data Analysis}

In the current study, data analysis procedures consisted of descriptive statistics, inferential statistics, i.e., Spearman's rho correlation coefficient. First of all, reliability of two grammatical proficiency tests (OSPT and PGPT) was examined by computing the internal consistency. Validity of these measures was also examined by measuring concurrent validity.

Second, descriptive statistics was performed for the instruments of the study. Test items were analyzed in the light of the average score (means), and variability (standard deviations).

Third, each variable was screened for missing data and outliers for the bilingual group. No missing values were identified while a small number of outliers (i.e., "cases with values well above or well below the majority of other cases" (Pallant, 2013, p. 66)) were identified. According to Tabachnick and Fidell (2007) "one option for reducing impact of univariate outliers is to change the score(s) on the variable(s) for the outlying case(s)" (p. 76). In accordance with this method, univariate outliers were assigned a raw score on the offending variable that was one unit larger or smaller than the next most extreme score.

Fourth, bilinguals' responses on two proficiency tests were also screened for normality separately as per Research Question using measures of skewness, kurtosis, histograms, and the Shapiro-Wilk statistic. The Shapiro-Wilk statistic was calculated as the bilingual group comprised 100 participants (Coakes \& Steed, 1999). The histograms indicated non-normal distributions for the variables of the Research Question and the statistics were not significant for these variables; therefore the non-parametric Spearman's rho correlation technique was run.

\section{Results}

To probe the null hypothesis concerning the correlation between L2 grammatical proficiency level (Persian) and L3 grammatical proficiency level (English), descriptive statistics and a Spearman's rho correlation coefficient were calculated. Table 1 displays the result of descriptive statistics for the overall performance of the bilingual group.

Table 1. Descriptive statistics of bilinguals' grammatical proficiency in L2 Persian and L3 English

\begin{tabular}{ccccccc}
\hline \multicolumn{8}{c}{ Descriptive Statistics } \\
\hline & \multicolumn{1}{c}{$\mathrm{N}$} & Minimum Maximum & Mean & Std. Deviation Std. Error Mean \\
\cline { 2 - 7 } OSPT & 100 & 8.00 & 37.00 & 17.5900 & 5.34864 & .53486 \\
PGPT & 100 & 16.00 & 45.00 & 26.8800 & 6.14354 & .61435 \\
Valid N (list wise) & 100 & & & & & \\
\hline
\end{tabular}


The result of the holistic descriptive statistics illustrated that the bilingual participants gained a higher mean in the PGPT $(M=26.88, S D=6.14)$ than in the OSPT $(M=17.59, S D=5.35)$.

Furthermore, the data obtained from the PGPT and OSPT were subjected to the statistical procedure of the Spearman's rho correlation coefficient. The result revealed that there was a moderate, positive correlation between the two variables, $r=.60, n=100, p<0.01$, with high levels of $\mathrm{L} 2$ grammatical proficiency associated with high levels of L3 grammatical proficiency. In other words, the observed positive relationship means that the increase in L2 grammatical proficiency leads to an increase in L3 grammatical achievement. Figure 1.shows the correlation between the performance of the bilingual participants on the PGPT and OSPT.

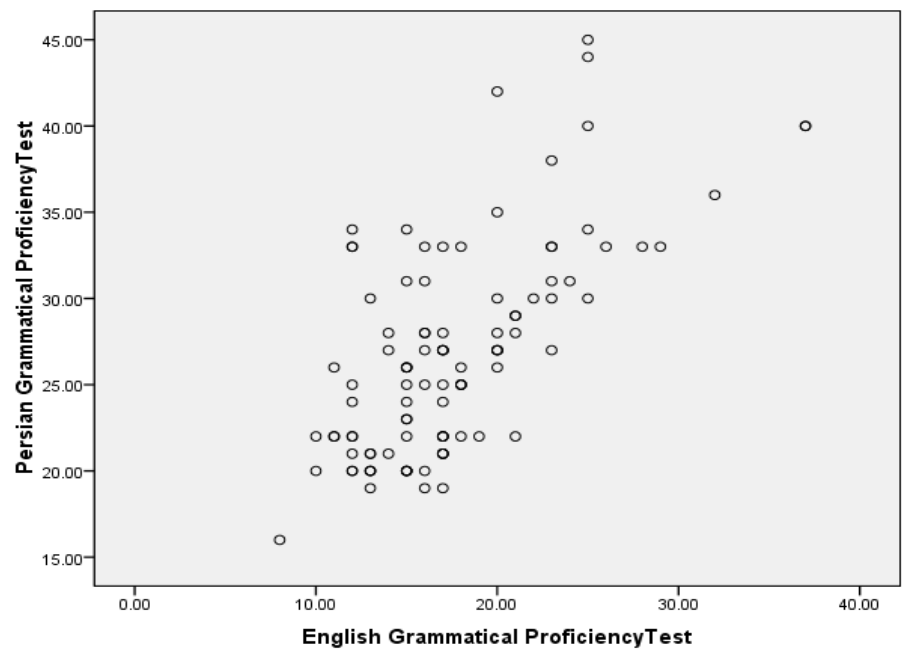

Figure 1. Correlation between OSPT and PGPT

As illustrated in Figure 1.amoderate, positive correlation existed between L2 grammatical proficiency level (Persian) and L3 grammatical proficiency level (English). Based on the finding, therefore, the null hypothesis stating that grammatical proficiency level in L2 (Persian) would not correlate with L3 grammatical proficiency level was firmly rejected.

\section{Discussion}

A number of studies have proved that good proficiency in an L2 leads to good proficiency in an L3 (Lasagabaster, 2000; Muñoz, 2000; Saeidi \& Mazoochi, 2013). According to Cenoz and Valencia (1994) "the level of bilingualism... is closely related to the level of proficiency in English..." (as cited in Cenoz, 2003, p. 75). Thus, it is expected a relationship can be found between L2 grammatical proficiency and L3 grammatical proficiency.

The results of this study confirm the theoretical assumption that there is a significant, positive relationship between these variables $(r=.60, p<0.01)$. The direction indicates that the participants relied on grammatical knowledge to succeed in L3 learning. In other words, this evidence may suggest that L3 participants were progressively more accurate as proficiency in Persian increased. That is, their accuracy in L3 increased with proficiency in L2 and aided the restructuring of L3 grammars. Therefore, this implies that if Azeri-Persian participants put serious efforts into improving their Persian grammatical proficiency, they would be expected to perform better. More specifically, this suggests that as L2 grammatical knowledge increases among the L3 participants, the tendency to have a better L3 grammatical knowledge will increase.

It is not surprising to see this significant and positive relationship between L2 grammatical Persian proficiency and L3 English grammatical proficiency since in Iran, a multicultural and multilingual society, bilingual learners study all of their courses in Persian, the majority language, throughout their education (the language of instruction is Persian). Furthermore, they start learning Persian literacy skills (reading and writing) at the age of seven and continue until their diploma. According to Thomas (1988) and Swain et al. (1990), formal instruction in one's previously acquired languages appears to be a pertinent factor in the acquisition of additional languages.

This explanation ties in with the issue that learners with good literacy skills in their previously acquired 
languages may be able to transfer some of these skills when learning an additional language, since schooling provides "phonological awareness, which is a prerequisite for reading alphabetic writing systems, narrative skills, and knowledge of textual conventions" (Montrul, 2008, p.143) for learners.

Based on Cummins' (1979) interdependence hypothesis "language skills will transfer from L1 to L2 if there is sufficient exposure to the L2 and motivation to learn the language" (p. 233, as cited in Sparks, Patton, Ganschow, \& Humbach, 2009, p. 205).This claim is also supported by Strucker and Davidson (2003) who argue that learners with literacy skills in their L1 can transfer these skills when learning second language literacy. This notion could be applied by extension to L3 learning; i.e. language skills will transfer from L2 to L3 if there is sufficient exposure to the L2 and motivation to learn the language. Therefore, the level of proficiency in TLA may be affected by the ability to read and write in the second language. In other words, the ability to read and write in the L2 may affect the level of proficiency in TLA.

To conclude, the result of this section supports the notion that "the learning of the L3 will be closely related to the proficiency of the learner in his or her L2: if L2 proficiency is high it will facilitate L3 learning; if low it may impede it" (Cummins, 1979, as cited in Lasagabaster, 2000, pp. 184-185).

The results conform to the studies by Lasagabaster (2000), Sanz (2000), and Muñoz (2000). Lasagabaster (2000) compared the level of proficiency in Basque, Spanish and English attained by students from six different schools and found that "if a high degree of competence is achieved in L1 and L2, then the L3 can be seen as having a beneficial effect in that it may promote and assist the development of greater metalinguistic awareness" (Lasagabaster, 2000, p. 195). In Muñoz's (2000) study in Catalonia, the results indicated that learners with a high level of proficiency in two other languages also presented a high level of proficiency in English as the L3.

Sanz (2000) compared the L3 English acquisition of Catalan-Spanish bilinguals with the L2 English acquisition of Spanish monolinguals and concluded that high level of proficiency in L2 facilitated the process of learning an L3.

Hence, according to the results of proficiency analysis, the null hypothesis stating that grammatical proficiency level in L2 (Persian) would not correlate with L3 grammatical proficiency level was firmly rejected.

\section{Conclusion}

The main purpose of this study was to establish factors pertinent to the acquisition of English as an L3 in Iran. In order to investigate this matter, data have been obtained through the instruments prepared for the present purpose. The respondents included in the investigation were 100 female Azeri-Persian bilingual high school students.

The theoretical framework suggests that L2 grammatical proficiency may also prove influential in TLA (Lasagabaster, 2000; Muñoz, 2000; Sanz, 2000, to name a few). The results of this study reveal that there is a significant and positive relationship between the L2 grammatical proficiency and the L3 grammatical proficiency which confirms the theoretical assumption that the bilinguals' grammatical accuracy in an L3 increases with grammatical proficiency in an L2.

It is clear from this study and the review of the related literature that proficiency, both in the first and subsequent languages, helps the learner to produce language. The results show learners with high proficiency level in their L2 obtain higher levels of proficiency in a third language and that proficiency in the second language has a positive effect and is essential for successful subsequent language acquisition (Lasagabaster, 2000; Sanz, 2000). The pedagogical implication that should be drawn from this analysis is that grammatical proficiency in the L1 and L2 should be focused since bilingual programs that promote first and second grammatical proficiency have an overall positive effect on the learning of other languages.

The current study has shed some light on the area of the effect of L2 grammatical proficiency on learning an additional language, but it has certain limitations and many more studies in this area may be highly worthwhile. The most obvious limitation present in the design of this study originates in the test administered to evaluate the participants' proficiency in English. As a consequence of the short period of contact time allowed and as grammar and vocabulary are heavily focused in Iranian EFL curriculum, the test included only a structure section and a vocabulary section. Therefore, the researchers cannot make claims about the participants' reading and oral skills. In other words, it cannot establish the respondents' overall English proficiency. Undoubtedly, the test could have been more extensive, including more test items estimating other language features. The researchers have, however, included test items which they believe will indicate the respondents' level of English proficiency to the extent possible in this investigation. 


\section{References}

Bachman, L. F. (1990). Fundamental considerations in language testing. Oxford: Oxford University Press.

Bachman, L. F., \& Palmer, A. S. (1996). Language testing in practice. Oxford: Oxford University Press. http://dx.doi.org/10.1177/026553229601300201

Bardel, C., \& Lindqvist, C. (2007). The role of proficiency and psychotypology in lexical cross-linguistic influence. A study of a multilingual learner of Italian L3. Retrieved from http://www.isd.su.se/

Cenoz, J. (2000). Research on multilingual acquisition. In J. Cenoz, \& U. Jessner, (Eds.), English in Europe: The acquisition of a third language (pp. 39-53). Clevedon, Buffalo, Toronto, Sydney: Multilingual Matters Ltd.

Cenoz, J. (2001). The effect of linguistic distance, L2 status and age on cross-linguistic influence in third language acquisition. In J. Cenoz, B. Hufeisen, \& U. Jessner (Eds.), Cross-linguistic influence in third language acquisition: Psycholinguistic perspectives (pp. 8-20). Clevedon, Buffalo, Toronto, Sydney: Multilingual Matters Ltd.

Cenoz, J. (2003). Cross-linguistic influence in third language acquisition: Implications for the organization of the multilingual mental lexicon. Bulletin VALS-ASLA (Vereinigung fürangewandte Linguistik in der Schweiz), $78,1-11$.

Cenoz, J. (2003). The additive effect of bilingualism on third language acquisition: A review. International Journal of Bilingualism, 7(1), 71- 87. http://dx.doi.org/10.1177/13670069030070010501

Cenoz, J. (2008). The influence of bilingualism on multilingual acquisition: Some data from the Basque country. Retrieved from http://webs.uvigo.es/

Cenoz, J. (2009). Towards multilingual education: Basque educational research in international perspective. Bristol, Buffalo, Toronto: Multilingual Matters Ltd.

Cenoz, J., \& Genesee, F. (Eds.). (1998). Beyond bilingualism: Multilingualism and multilingual education. Clevedon, Philadelphia, Toronto, Sydney, Johannesburg, Sydney: Multilingual Matters Ltd.

Cenoz, J., \& Jessner, U. (Eds.). (2000). English in Europe: The acquisition of a third language. Clevedon, Buffalo, Toronto, Sydney: Multilingual Matters Ltd.

Cenoz, J., Hufeisen, B., \& Jessner, U. (Eds.). (2001). Cross-linguistic influence in third language acquisition: Psycholinguistic perspectives. Clevedon, Buffalo, Toronto, Sydney: Multilingual Matters Ltd.

Cenoz, J., Hufeisen, B., \& Jessner, U. (Eds.). (2003). The multilingual lexicon. New York, Boston, Dordrecht, London, Moscow: Kluwer Academic Publishers. http://dx.doi.org/10.1007/b101932

Coakes, S., \& Steed, L. (2005). SPSS: Analysis without Anguish: Version 12.0 for windows. John Wiley \& Sons Australia, Ltd.

Cohen, L., Manion, L., \& Morrison, K. (2007). Research methods in education. London, New York: Routledge, Taylor \& Francis Group.

Edwards, J. (1994). Multilingualism. London, New York: Routledge, Taylor \& Francis Group. http://dx.doi.org/10.4324/9780203430927

Edwards, L. (2007). Oxford Solutions Placement Test. Oxford: Oxford University Press.

Falk, Y. (2010). Gingerly studied transfer phenomena in L3 Germanic syntax. The role of the second language in third language acquisition. Retrieved from http://repository.ubn.ru.nl/

Falk, Y., \& Bardel, C. (2010). The study of the role of the background languages in third language acquisition. The state of the art. Retrieved from http://repository.ubn.ru.nl/

Farhadian, M., Rohani, A, Mariani, M., Redzuan, M., Gazanizadand, N., \& Kumar, V. (2010). Theory of mind in bilingual and monolingual preschool children. J. Psychology, 1(1), 39-46.

Hufeisen, B. (2000). A European perspective: Tertiary languages with a focus on German as L3. In J. W. Rosenthal (Ed.), Handbook of undergraduate second language education (pp. 209-230). Mahwah, New Jersey, London: Lawrence Erlbaum Associates, Inc.

Kassaian Z., \& Esmae'li, S. (2011). The Effect of bilinguality on L3 breadth of vocabulary knowledge and word reading skill. Theory and Practice in Language Studies, 1(8), 966-974. http://dx.doi.org/10.4304/tpls.1.8.966-974

Keshavarz, M. H., \& Astaneh, H. (2004). The impact of bilinguality on the learning of English vocabulary as a 
foreign language (L3). Bilingual Education and Bilingualism, 7(4), 295-302. http://dx.doi.org/10.1080/13670050408667814

Khany, R., \& Bazyar, A. (2014). Generative analysis of the acquisition of negation by Iranian EFL learners: A typological study. Journal of Research in Applied Linguistics Studies, 4(1), 62-87.

Larsen-Freeman, D. (1991). Teaching grammar. Retrieved from http://www.uibk.ac.at

Lasagabaster, D. (2000). Three languages and three linguistic models in the Basque educational system. In J. Cenoz, \& U. Jessner, (Eds.), English in Europe: The acquisition of a third language (pp. 179-197). Clevedon, Buffalo, Toronto, Sydney: Multilingual Matters Ltd.

Lindqvist, C. (2009). The use of the L1 and the L2 in French L3: Examining cross-linguistic lexemes in multilingual learners' oral production. International Journal of Multilingualism, 6(3), 281-297. http://dx.doi.org/10.1080/14790710902812022

Modirkhamene, S. (2008). Metalinguistic awareness and bilingual vs. monolingual EFL learners: Evidence from a diagonal bilingual context. The Journal of Applied Linguistics, 1(1), 66-102.

Montrul, S. A. (2008). Incomplete acquisition in bilingualism: Re-examining the age factor. Amsterdam: John Benjamins B.V. http://dx.doi.org/10.1075/sibil.39

Muñoz, C. (2000). Bilingualism and trilingualism in school students in Catalonia. In J. Cenoz, \& U. Jessner (Eds.), English in Europe: The acquisition of a third language (pp. 157-178). Clevedon, Buffalo, Toronto, Sydney: Multilingual Matters Ltd.

Pallant, J. (2013). SPSS survival manual: A step by step guide data analysis using IBM SPSS (5th ed.). Maidenhead: Open University Press/McGraw Hill. http://dx.doi.org/10.1080/00396338.2013.784467

Purpura, J. E. (2004). Assessing grammar. UK: Cambridge University Press. http://dx.doi.org/10.1017/CBO9780511733086

Ringbom, H. (1987). The role of the first language in foreign language learning. Clevedon, Philadelphia: Multilingual Matters Ltd.

Saeidi, M., \& Mazoochi, N. (2013). A comparative study on bilingual and monolingual Iranian EFL learners' linguistic intelligence across genders. Life Sci. J., 10(6s), 321-334.

Sanz, C. (2000). Bilingual education enhances third language acquisition: Evidence from Catalonia. Journal of Applied Psycholinguistics, 21, 23-44.

Sparks, R., Patton, J., Ganschow, L., \& Humbach, N. (2009). Long-term crosslinguistic transferof skills From L1 to L2. Language Learning, 59(1), 203-243. http://dx.doi.org/10.1111/j.1467-9922.2009.00504.x

Strucker, J., \& Davidson, R. (2003). Adult reading component study (ARCS). A NCSALL research brief. NCSALL $1-4$.

Swain, M., Lapkin, S., Rowen, N., \& Hart, D. (1990). The role of mother tongue literacy in third language learning. Language, Culture and Curriculum, 3(1), 65-81. http://dx.doi.org/10.1080/07908319009525073

Tabachnick, B. G., \& Fidell, L. S. (2007). Using multivariate statistics. Boston: USA. Pearson Education, Inc.

Thomas, J. (1988). The role played by metalinguistic awareness in second and third language learning. Journal $\begin{array}{llll}\text { of Multilingual and Multicultural Development, } & \text { 9, 235-246. }\end{array}$ http://dx.doi.org/10.1080/01434632.1988.9994334

Williams, S., \& Hammarberg, B. (1998). Language switches in L3 production: Implications of a polyglot speaking model. Applied Linguistics, 19(3), 295-333. http://dx.doi.org/10.1093/applin/19.3.295

\section{Copyrights}

Copyright for this article is retained by the author(s), with first publication rights granted to the journal.

This is an open-access article distributed under the terms and conditions of the Creative Commons Attribution license (http://creativecommons.org/licenses/by/3.0/). 